protecting an individual client's identity. In these situations, in which a substantial prejudice factor is involved, the courts should promote freedom of consultation by protecting the client's identity in the same manner as they protect any other confidential communication to an attorney.

\title{
MEDICAL DEDUCTION: TEST AND APPLICATION
}

The Internal Revenue Code of 1954 provides relief for taxpayers who have incurred substantial medical costs during the tax year. ${ }^{1}$ Section 2132 allows a limited ${ }^{3}$ deduction of "the expenses ... for medical care of the taxpayer, his spouse, or a dependent...."4 Although the original purpose of the allowance was not clearly explained, 5 the medical deduction is now generally recognized as an additional element of "ability to pay" considerations in the federal income tax system. 6

The expenses of medical care, as defined by the Code, are the amounts paid "for the diagnosis, cure, mitigation, treatment, or prevention of disease, or for the purpose of affecting any structure or function of the body (including amounts paid for accident or health insurance), or ... for transportation primarily for and essential to... [the enumerated functions]."7 The courts have encountered several recurring problems in applying this definition of medical expense. It was not made clear, for example, whether expense

1 By providing tax reductions to those who have incurred medical costs, Congress inflicts a greater burden upon other taxpayers. Thus, to a degree, the costs of illness are diffused throughout the society. For analyses of the economic effects of this form of "socializing" medical care, see Kahn, Personal Deductions in the Federal Income Tax 126-61 (1960); Jensen, Medical Expenditures and Medical Deduction Plans, LX J. PoL. Econ. 503-24 (1952).

2 A medical deduction was originally provided in 1942 as an amendment to the 1939 Code. Revenue Act of $1942, \S 127,56$ Stat. 825 . The definition of allowable deductions was substantially maintained in the 1954 Code.

${ }^{3}$ Section 213 (a) stipulates that only medical costs in excess of $3 \%$ of adjusted gross income are deductible. Sections $213(\mathrm{c})$ and $213(\mathrm{~g})$ establish maximum amounts per person.

4 INT. REv. CODE OF 1954, $\$ 213$ (a). A deduction is not the sole means of providing tax relief for medical expenses. For a discussion of alternative proposals, see Jensen, Rationale of the Medical Expense Deduction, 7 NAT'L TAX J. 274 (1954).

5 There is, for example, evidence that the deduction was to be a temporary, wartime relief measure. S. REP. No. 1631, 77th Cong., 2d Sess. 6 (1942): "This allowance is recommended in consideration of the heavy tax burden that must be borne by individuals during the existing emergency and of the desirability of maintaining the present high level of public health and morale."

${ }^{6}$ See Note, Medical Deduction: Scope and Purpose, 28 IND. L. J. 264 (1953). Judge Frank viewed the provision as an unparalleled display of legislative charity. Dissenting in Ochs v. Commissioner, 195 F.2d 692, 695 (2d Cir. 1952), he observed that, in allowing a deduction for medical costs, "for once, Congress, although seeking revenue, shows it has a heart...."

7 INT. REv. CODE OF 1954, § 213(e). 
was to include expenditures normally designated as capital in nature. Also, the definition of medical could not be implemented without the use of more specific directives to provide a consistent basis for the disposition of deduction claims.

Since no legislative clarification was forthcoming, the courts were left to their own devices. Despite the difficulty of the task, there has been little published criticism of the manner in which these problems have been resolved. 8 Difficult cases, however, continue to arise. An examination of the means by which courts have disposed of prior controversies may be beneficial in the attempt to resolve current disputes.

\section{I}

The contrasting concepts of deductible expenses and non-deductible capital expenditures is familiar to tax practitioners. Since the Code provision establishes a deduction only for medical "expenses," the deductibility of ordinarily capital expenditures made for medical reasons was disputed. In a 1950 case, 9 the Tax Court held that the cost of an oil-burning furnace, obtained through a wartime priority resulting from a physician's affidavit, was not deductible as a medical expense. The taxpayer, submitting the physician's statement, claimed that the purchase had been necessitated by irritations caused by a coal furnace which aggravated asthma, hay fever and chronic sinusitus conditions among the members of the household. The validity of this claim was not judged. The court said that the cost was a capital expenditure of permanent benefit to the family and that capital expenditures were non-deductible throughout the Code.10

The rationale of the "oil furnace" case was the basis for the disallowance of several similar claims. The principle was not confined, however, to cases where permanent benefit had accrued to the taxpayer. In Estate of $C$. $L$. Hayne, ${ }^{11}$ for example, the installation of an elevator in the home of a partially paralyzed invalid was held non-deductible on the authority of the oil furance case12 even though there was evidence that the value of the property had been reduced. ${ }^{13}$ Immediately thereafter, in Edna G. Hollander, 14 the Hayne decision

${ }^{8}$ But see Bardes, What Is Meant by Medical Expense?, N.Y.U. 11TH INST. ON FeD. TAX 1227 (1953).

9 John L. Seymour, 14 T.C. 1111 (1950).

10 Id. at 1118: "We are unable to find in the history of the statute any evidence of an intent by Congress to create an exception to the general rule that capital expenditures are not deductible as current expenses."

1122 T.C. 113 (1954).

$12 I d$. at 122: "Under the authorities cited we think the cost of the installation of the elevator undoubtedly was a capital expenditure and hence is not deductible...." The court also suggested that the expense was incurred to solve a transportation problem which was merely incidental to the illness.

${ }^{13} \mathrm{Id}$. at 121.

1422 T.C. 646 (1954). 
was used to disallow the deduction of an inclinator purchased for the home of one recovering from a coronary thrombosis. 15

The Third Ciruit reversed Hollander on appeal.16 The court found that "there is no specific statutory direction of non-deductibility [for this type of expenditure]."17 Also, it observed that the Commissioner's stand on capital expenditures was ambivalent for, although this case was vigorously contested, other capital expenditures were explicitly allowed: "The Commissioner's own regulations... include a medical deduction for 'artificial teeth or limbs." "18 Restrictions of precedent having been removed, the congressional intent was examined and the deduction allowed: "It seems to us that we are here dealing with a true medical expense under the letter and spirit of the Code."19

The Hollander decision has generally been followed.20 However, in Frank $S$. Delp,21 the prior Tax Court cases were followed, producing an interesting result: "Accordingly, although the expenditure in question was made solely for the purpose of mitigating a physical ailment, was prescribed by a physician, and bore a close relationship to the illness of Edna Delp both in time and effectiveness of treatment, thereby falling within the ambit of section 213(e)(1) of the 1954 Code, [the claim is disallowed]."22

The recurrence of similar results is not expected. The Commissioner no longer insists that all capital expenditures are non-deductible: "[E]xpenditures made for medical purposes will not be disallowed merely because they are of a capital nature. However, it is the position of the Service that the capital nature of an expenditure will be a consideration in determining its deductibility. If such expenditures constitute amounts paid out for permanent improvements which increase the value of any property or estate, they will not be allowed as medical expense deductions." 23 The meaning of "expense" was substantially resolved in this manner; the definition of "medical" presents a continuing problem.

\section{II}

To administer the medical relief provision, it has been necessary to distinguish the expenditures for which the deduction is allowed from those personal,

15 Id. at 648: "The case is not distinguishable in principle from Estate of C. $L$. Hayne...."

16Hollander v. Commissioner, 219 F.2d 934 (3d Cir. 1955).

17 Id. at 936-37 n.4.

18 Id. at 936.

19 Id. at 937.

20 Berry v. Wiseman, 174 F. Supp. 748 (W.D. Okla. 1958); Post v. United States, 150 F. Supp. 299 (N.D. Ala. 1956); Snellings v. United States, 149 F. Supp. 825 (E.D. Va. 1956.

2130 T.C. 1230 (1958).

$22 I d$. at 1235.

23 Rev. Rul. 411, 1959-2 Cum. Bull. 100-01. 
non-deductible expenses which have a beneficial effect upon the health of an individual, but which are incurred as normal costs by a significant sector of the population.24 Thus, expenditures for personal hygiene and general health improvement have been disallowed. ${ }^{25}$ Since the purpose of the deduction is to provide relief for unusual expenses, this general exclusion is wholly consistent with the provision. Not all claims are so easily resolved.

The legislative definition could have been made rigid and specific. For example, Congress might have created an exclusive list of particular allowable expenses. 26 The expenses listed would then constitute the sole items of deductible medical care. Other costs, regardless of medical value in particular instances, would be automatically disallowed.

Instead, a method permitting maximum flexibility was chosen. The allowance of a claimed deduction depends upon sufficient demonstration of a causal connection between a specific malady and the expense incurred.27 Thus, it has been said that "a deduction may be claimed only for such expense as is incurred primarily for the prevention or mitigation of the particular physical or mental defect or illness." 28 The same difficulties that beset courts whenever proximity is relevant prevent a more specific statement of the rule. The decision is rendered as a factual determination. 29 The burden of proof, of course, is upon the taxpayer.

The generality of the rule has limited its value in determining the deductibility of a particular claim. To apply the statutory definition, therefore, certain tests were evolved to provide a reasonably consistent basis for decision. The taxpayer must generally show that a specific illness existed, 30 that the expenditure was made in a reasonable attempt to avoid harms created by the illness, ${ }^{31}$ and that the expenditure was not made for personal, nonmedical benefit. 32

24 See Bittker, Federal Income Estate and Gift TaXation 158-65 (1955 ed.); SURREY \& WARREN, FEDERAI INCOME TAXATION 328-35 (1960 ed.).

25 Treas. Reg. § 1.213-1(e)(ii) (1957); Rev. Rul. 261, 1955-1 CuM. Bull. 307, 312.

26 See Note, supra note 6, at 268-69.

27 Edward A. Havey, 12 T.C. 409, 412 (1949): "To be deductible as medical expense, there must be a direct or proximate relation between the expense and the diagnosis, cure, mitigation, treatment, or prevention of disease or the expense must have been incurred for the purpose of affecting some structure or function of the body."

28 L. Keever Stringham, 12 T.C. 580, 584 (1949).

29 Commissioner v. Stringham, 183 F.2d 579 (6th Cir. 1950).

${ }^{30}$ See text accompanying note 25 supra.

31 Cf. Vincent P. Ring, 23 T.C. 950 (1955), where a journey to the religious shrine at Lourdes was held to be in quest of spiritual, not physical, aid.

32 Cf. John J. Thoene, 33 T.C. No. 8 (Oct. 21, 1959), where the cost of dancing lessons was disallowed although there was evidence that the lessons were advised by a physician to provide the taxpayer with light exercise during post-surgery recovery. 
Several factors are commonly considered in the application of these tests. Although some medical benefit may collaterally accrue from an expenditure, the deduction will be disallowed where the taxpayer intended the expenditure for other purposes. ${ }^{33}$ The motives of the taxpayer will not be solely determinative, however. ${ }^{34}$ The advice of a competent physician may be relevant. 35 Proximity of the causal relationship between the illness and the expense will also be examined. ${ }^{36}$ The relative weight given to these factors depends upon the context within which evidence is presented. The substantiating statement of an unrelated physician, for example, might be accepted more readily than that of the taxpayer's physician-husband. In another instance, the expenditure might be so common that no physician's opinion could sustain the deduction.

It is futile, therefore, to seek an established formula with universal application. ${ }^{37}$ An observation of the matters considered and the method employed must suffice.

\section{III}

The deduction, to reflect the legislative intention accurately, should be allowed only to the extent that the illness has increased the taxpayer's financial burden. In Rodgers $v$. Commissioner, ${ }^{38}$ the taxpayer claimed a deduction for the cost of travel allegedly necessitated by illness. Since the trips were substantially similar to his pre-illness travel, the taxpayer failed. An increase in his financial burden had not been proved.

A single expenditure may yield both medical and non-medical benefit. In such a case, the problem of determining an increased financial burden poses peculiar difficulty. Since no solution was suggested by the statute, the dilemma was again left to the courts.

In the frequently discussed ${ }^{39}$ case of Ochs $v$. Commissioner, ${ }^{40}$ the court

33 See Arnold Namrow, 33 T.C. No. 50 (Nov. 30, 1959), where the expenditure of a psychiatry student for his own analysis, an experience necessary to his education, was not deductible as a medical espense.

34 Edward A. Havey, 12 T.C. 409, 412 (1949): "To accord it conclusive weight would make nugatory the prohibition against allowing personal, living, or family expenses."

35 Ibid.

${ }^{36}$ L. Keever Stringham, 12 T.C. 580, 584 (1949): "The Congressional intent is sufficiently evident to require the showing of the present existence or the imminent probability of a disease, physical or mental defect, or illness ...." (Emphasis added.)

37 Cf. Commissioner v. Stringham, 183 F.2d 579 (6th Cir. 1950): "Each case of this character must be decided on its own particular facts, and an opinion from us could create no rule of thumb for determination of the applicability of the term 'medical care' to all cases which may arise."

38241 F.2d 552 (8th Cir. 1957).

39 See authorities cited note 24 supra.

40195 F.2d 692 (2d Cir. 1952), cert. denied, 344 U.S. 827 (1952). 
of appeals, affirming the Tax Court, ${ }^{41}$ allowed as a deduction no part of the cost of sending children to a boarding school to relieve tensions upon their mother, who was attempting to recover from a serious operation for the removal of a malignancy, and to avoid the recurrence of the throat cancer. The conclusion of the Tax Court was particularly interesting in view of the circumstances explicitly noted in the opinion:

Petitioner's two children have not attended private school but have lived at home and attended public school since a period beginning 5 years after the operation of December 10, 1943. Petitioner's purpose in sending the children to boarding school during the year 1946 was to alleviate his wife's pain and suffering in caring for the children by reason of her inability to speak above a whisper and to prevent a recurrence of the cancer which was responsible for the condition of her voice.42

Moreover, neither the veracity nor the good faith of the taxpayer was doubted.43 Although taking cognizance of the Tax Court's comments, the court of appeals held that the amounts claimed were non-deductible family expenses. 44 Despite the acknowledged medical needs, the non-medical benefit which collaterally accrued resulted in total disallowance. Judge Frank, in a dissenting opinion, applied the usual tests and argued that a portion of the expenditure was a justifiable deduction. 45 The deduction, he concluded, should be allowed, reduced by the value of the personal benefit to the family for care and education of the children. 46

Judge Frank's opinion suggests a desirable solution. Since the purpose of the deduction provision is to relieve taxpayers burdened by unusual medical costs, the amount of the financial burden attributable to medical benefit should be allowed where a reasonable basis for an apportionment is available. Thus, where an expense incurred primarily for medical care produces collateral personal, non-medical benefit, the deduction is the amount by which the expenditure exceeds the value of the collateral benefit.

Apportionments have been employed in several controversies. In William B. Meister, ${ }^{47}$ for example, where sudden illness forced the use of more rapid transportation between two cities than the taxpayer had previously planned for pleasure, only the difference in cost between the original and the substitute means of transportation was allowed. A ruling by the Commissioner provides that the cost of a special diet, required for medical purposes, will be deductible to the extent that normal food expenditures have been exceeded. 48 The total expense of the prescription diet is not allowable because the amount equal

${ }^{41}$ Samuel Ochs, 17 T.C. 130 (1951).

$42 I d$. at 132.

43 Id. at 134.

44195 F.2d at 694.

- 45 Id. at 695.

4718 CCH Tax Ct. Mem. 889 (1959).

$46 \mathrm{Id}$. at 697.

48 Rev. Rul. 261, 1955-1 Cum. BuLl. 307, 312. 
to the taxpayer's normal food cost is merely a substitute for personal expense. 49

Apportionments are appropriate in many other cases. Insurance premiums for medical care are deductible under section 213.50 When a policy provides for other benefits, only that portion of the premium attributable to the cost of medical care insurance can be justified as a medical deduction.51

The regulations suggest that wherever a capital expenditure bestows permanent benefit, the expenditure may be wholly disallowed.52 If the requisites of the statutory definition are fulfilled, the amount by which the total cost exceeds the value of the permanent benefit would seem to be deductible.

\section{IV}

Application of the tests generally and attempts to apportion particularly are extremely difficult in some cases. An alternative to this flexible application of the legislative definition which might reduce the hardship of deciding such cases would be a specific enumeration of deductible items. The statutory definition of "medical care" was varied by the 1954 Code explicitly to include transportation expenses "primarily for and essential to" the usual functions of medical care. 53 It is arguable that this change was intended to add an element of rigidity to the definition.

There is, however, no indication that flexibility has thereby been reduced. Under the prior statute, deduction was allowed where the travel expenditure fit the definition of medical care. ${ }^{54}$ Likewise, travel expenses are not deductible under the 1954 Code unless the requisites of the definition have been proved. If the general tests are unchanged, therefore, transportation expenses deductible under the addition to the 1954 Code should have been allowed under the earlier provisions.

49 See Estate of Eugene Merrick Webb, 30 T.C. 1202 (1958); Doris V. Clark, 29 T.C. 196 (1957).

50 INT. Rev. CoDe of 1954, § 213(e).

51 Cf. Pyle, Accident and Sickness Insurance Under Code Sections 104, 105, 106 and 213, 34 TAXES 363, 374 (1956): "Since only that portion of the policy covering benefits which reimburse the insured for medical expense reduces his otherwise allowable medical deductions under [the relief provision], only that part of the premium paid by the taxpayer which is attributable to the medical benefits of such policy may be considered a deductible medical expense." But see, Heard v. Commissioner, 269 F.2d 911 (3d Cir. 1959), where the total premium was allowed.

52 See text accompanying note 23 supra.

53 INT. Rev. CODE OF 1954, § 213(e).

54 Cf. Commissioner v. Stringham, 183 F.2d 579 (6th Cir. 1950), where the expenses necessary to send a girl with lung disease to a more favorable climate were held to be deductible. Although some claims of medical deduction for transportation were denied because the requisites of "medical care" had not been sufficiently demonstrated, there is no indication that the denial was made solely because a travel expense was in question. See Samuel Dobkin, 15 T.C. 886 (1950); Edward A. Havey, 12 T.C. 409 (1949). 
There are indications that the explicit allowance of travel costs was meant to signify an implicit disallowance of certain other expenses. Legislative reports compiled in 1954 noted that lodging and food expenditures, presumably because of the difficulty in determining medical benefit and increased financial burden, should be non-deductible.55 Despite this admonition, courts have allowed both lodging and food costs to be deducted as medical expenses where sufficient proof has been submitted.56

It is interesting to note that the deductibility of food and lodging expenses during hospitalization is expressly permitted by the Commissioner. ${ }^{57}$ Medical deduction claims for food and lodging apart from hospitalization may be equally valid. If the taxpayer has proved that his financial burden has been increased without a corresponding increase in personal, non-medical benefit, the deduction should be allowed. A contrary result will contravene the intended benefits of the relief provision.

The main argument for making the definition of "medical care" more rigid is that litigation would be reduced. 58 This contention is not wholly tenable. Although travel expense has been explicitly included, litigation has not been eliminated.59 Unless the enumeration would exclude borderline cases, the same problems of definition will occur and litigation or compromise will be necessary. But if the difficult items are excluded merely because of the difficulty, the purpose of the provision will have been compromised by disallowing expenses which, in fact, had been incurred for "medical care."

Moreover, it is not clear that there are no bases for prediction under the current practice. The continual litigation of certain types of claims tends to provide indicators from which the degree of evidence necessary to support a claim can reasonably be predicted. 60 Thus the weight of the burden of proof might rest a hundred-fold more heavily upon one claiming a medical deduction for carfare than for a surgeon's fee. The taxpayer who can suc-

55 H.R. REP. No. 1337, 83d Cong., 2d Sess. 30 (1954); S. REP. No. 1622, 83d Cong., 2d Sess. 218, 219 (1954): "The deduction permitted for "transportation primarily for and essential to medical care' clarifies existing law in that it specifically excludes deduction of any meals and lodging while away from home receiving medical treatment."

56 Embry v. Gray, 143 F. Supp. 603 (W.D. Ky. 1956); Robert M. Bilder, 33 T.C. No. 155 (Oct. 26, 1959). In Max Carasso, 34 T.C. No. 119 (Sept. 30, 1960), the claim was disallowed, but the court declined to state a general rule: "There is no showing that the meals and hotel item herein was proximately related to medical care, apart from its being included in the traveling expenses. We express no opinion as to whether meals and lodging expenses might be deductible in other circumstances."

57 Treas. Reg. $\$ 1.213-1(\mathrm{e})(\mathrm{v})(1957)$. See also S. REP. No. 1622, 83d Cong., $2 \mathrm{~d}$ Sess. 218, 219 (1954).

s8 Others might suggest increased rigidity as a matter of fiscal policy to reduce the total amount of the benefit. Such a reduction could be achieved more equitably and accurately, however, by changing the minimum percentage and/or maximum amount provisions.

59 Cf. S. D. Winderman, 32 T.C. 1197 (1959).

60 Cf. Francis Hoffman, 17 T.C. 1380, 1386 (1952). 
cessfully bear the heavy burden, however, will not be penalized by an arbitrary disallowance. He can attempt to show the merits of his particular claim and will be judged thereon. If he chooses to contest a decision by the Commissioner, he does so with full knowledge of the difficulty.

The practice of medicine is continually changing with the increased accumulation of knowledge. A provision for tax relief must be sufficiently flexible to keep pace with these changes. The current definition of medical care, when applied by using the general tests, allows for such changes. As long as the purpose of the tax relief is to aid those afflicted with unusual medical burdens, the attainment of that goal should not be inhibited by a provision which may withhold the relief from the most burdened taxpayers.

\section{FORUM-SHOPPING IN THE REVIEW OF NLRB ORDERS}

A party who the National Labor Relations Board finds has committed an unfair labor practice may seek review of the Board's order in a United States Court of Appeals, 1 or the Board itself may petition a court of appeals to obtain judicial sanction for its order. ${ }^{2}$ The purpose of this comment is to explore the possibility of forum-shopping, ${ }^{3}$ especially with respect to an appeal by an aggrieved party, 4 and to determine the extent to which forum-shopping is practiced.

\section{I}

The accompanying chart comprises all cases decided by the courts of appeals from January, 1955, through November, 1960,5 in which the NLRB brought enforcement proceedings or an aggrieved party appealed a final Board order. The cases are tabulated with reference to the aggrieved party: an employer, a union or both. 6 A court's action with reference to each category

161 Stat. 148-49 (1947) (amended by 72 Stat. 945 (1958)), 29 U.S.C. $\S 160(f)$ (1958), hereinafter referred to as section 10(f), the section designation of the Labor Management Relations Act (Taft-Hartley Act), 61 Stat. 136 (1947).

261 Stat. 147-48 (1947) (amended by 72 Stat. 945 (1958)), 29 U.S.C. § 160(e) (1958), hereinafter referred to as section 10(e), the section designation of the Labor Management Relations Act (Taft-Hartley Act), 61 Stat. 136 (1947).

3 For the purposes of this comment, the term "forum-shopping" is applied whenever an appeal is taken to a court of appeals in a circuit other than where the unfair labor practice occurred, or where the aggrieved party has his principal place of business. In these situations, it will be assumed that the primary reason for the choice of forum is convenience.

4 An aggrieved party can be one against whom an order of the Board is issued, one who has had a complaint dismissed by the Board, or one who is partially in either category. See e.g., Kovach v. NLRB, 229 F.2d 138 (7th Cir. 1956); American Newspaper Publisher's Ass'n v. NLRB, 190 F.2d 45 (7th Cir. 1951); Albrecht v. NLRB, 181 F.2d 652 (7th Cir. 1950). Compare Amalgamated Meat Cutters \& Butcher Workmen v. NLRB, 267 F.2d 169 (1st Cir. 1959).

5 West Federal Reporter, Second Series, 218 F.2d to 284 F.2d.

6 Included in the category "orders against both" are those cases in which the Board's final order remedied only a portion of the alleged unfair labor practices for which the com- 